Горян Э.В.

\title{
НЕКОТОРЫЕ АСПЕКТЫ ПРИМЕНЕНИЯ ТАМОЖЕННОЙ ПРОЦЕДУРЫ СВОБОДНОЙ ТАМОЖЕННОЙ ЗОНЫ И ТАМОЖЕННОГО КОНТРОЛЯ НА ТЕРРИТОРИИ СВОБОДНОГО ПОРТА ВЛАДИВОСТОК
}

Аннотация. Предметом исследования являются положения национального законодательства, устанавливающие порядок осуществления таможенной процедуры свободной таможенной зоны и таможенного контроля на территории свободного порта Владивосток. Автор исследовал доктринальные наработки в указанной сфере, а также зарубежное законодательство. Ввиду новизны такого правового режима и небольшого срока его действия в Приморском крае отсутствует правоприменительная практика, позволяющая сделать вывод о недостатках правого регулирования, однако автор остановился на аспекте нормативного закрепления требований к территории, на которой применяется таможенная процедура свободной таможенной зоны и осуществляется таможенный контроль. Методология исследования определяется объектом и задачами исследования и включает методы анализа и синтеза, дедукции и индукции, а также сравнительно-правовой и историко-правовой методы. Использование данных методов имело комплексный характер. Основным выводом автора является тезис о необходимости осуществления жесткого нормативного регулирования применения таможенной процедуры свободной таможенной зоны и таможенного контроля на территории свободного порта Владивосток в части определения требований к территории, где резиденты свободного порта Владивосток будут осуществлять свою деятельность. Данный вывод автора базируется на исследовании опыта США и опыта функционирования зоны порто-франко на Дальнем Востоке в ХІХ-ХХ вв.

Ключевые слова: особые экономические зоны, таможенные процедуры, таможенный контроль, свободный порт Владивосток, внешнеторговая зона, резидент, коррупция, правовой режим, товары, таможенные органы.

Abstract. The research subject includes the provisions of national legislation regulating the free customs zone in and customs control over the free port of Vladivostok. The author studies the doctrinal groundwork and foreign legislation in this sphere. Due to the novelty of such a legal regime in Primorsky krai, there is no law enforcement practice which could help reveal the shortcomings of legal regulation, but the author considers the aspect of normative stipulation of the requirements to the territory on which the free customs zone procedure and customs control is applied. The research methodology is conditioned by the research object and tasks and includes the methods of analysis and synthesis, deduction and induction, the comparative-legal and historical-legal methods. These methods are used as a system. The author states the necessity of strict normative regulation of application of a free customs zone procedure and customs control on the territory of the free port of Vladivostok related to territorial requirements. This conclusion is based on the study of the experience of the USA and the porto franco zone functioning in the Far East in the 19th - 20th centuries.

Key words: the free port of Vladivostok, foreign trade zone, resident, corruption, legal regime, goods, customs agencies, customs control, customs procedure, special economic zone.

$\mathrm{T}$ ерритории с особым экономическим режимом набирают всё большую популярность в государствах, поставивших цель привлечь инвестиции и вывести экономику на более высокий уровень. Современные модели таких территорий варьируются от зон экспортной переработки в странах с развивающей экономикой до различных типов свободных зон и гибких процедур ввоза в большинстве крупных торговых стран. Науке и практике известны многочисленные терминологические определения подобных режимов: особые экономические зоны (КНР, РФ), свободные промышленные зоны (Ирландия), зоны свободного экспорта, квалификационные промышленные зоны (Иордания, Египет), свободные зоны (Объединенные Арабские Эмираты), зоны обработки беспошлинного экспорта (Республика Корея), внешнеторговая зона (США) и проч. Общими для всех этих видов характеристиками является специальный таможенный режим, предусматривающий беспошлинный экспорт и отсроченное взимание таможенных пошлин и акцизных сборов в сочетании с другими инвестиционными стимулами. Специальные процедуры позволяют предпринимателям отсрочивать формальное таможенное оформление ввоза иностранных товаров, сообщая об этом в таможенные органы и оставляя товар на такой территории. Товар экспортируется без упла- 
ты таможенных пошлин и определенных акцизных сборов, а товары, продаваемые на внутреннем рынке, облагаются налогом при поступлении на него. Деятельность резидентов в зоне порто франко может варьироваться от складского хранения до производства комплектующих или готовой продукции. В связи с этим возникает необходимость в исследовании особенностей осуществления таможенных процедур и таможенного контроля в подобных зонах.

Федеральный закон от 13.07.2015 №212-Ф3 «0 свободном порте Владивосток» (далее Ф3-212) рассматривает территорию свободного порта Владивосток (далее - СПВ), на которой применяется таможенная процедура свободной таможенной зоны (далее - СТЗ), как особую экономическую зону, поэтому особую важность получает вопрос осуществления этой таможенной процедуры, а также полномочий таможенных органов. От их деятельности не в последнюю очередь зависит эффективность работы резидентов СПВ, что влияет на инвестиционный климат в Приморье. Кроме того, практика создания зон с подобным правовым режимом свидетельствует о том, что они выгодны высокотехнологичным производствам, а это значит и привлечение высококвалифицированной рабочей силы, и высокая добавленная стоимость продукции. Учитывая отток инвестиций из России в последние два года, так называемый проект СПВ должен оправдать ожидания инвесторов и общества. Недостатки российской правовой системы в виде зарегулированности отношений, коррупциогенности правовых норм и неэффективной судебных органов могут и в случае с СПВ привести к отрицательному результату.

В юридической литературе указанный аспект функционирования особых экономических зон вообще и свободного порта Владивосток освещен недостаточно полно. Теоретики исследуют как общие вопросы формирования и функционирования особых экономических зон в Российской Федерации (М.Г. Грец [1], А.П. Сысоев [2]), так и конкретные вопросы: С.А. Ларионов исследовал генезис таможенной процедуры свободной таможенной зоны в процессе интеграции РФ в международную торговлю [3], К.Н. Нилов указал на определенные проблемы функционирования особой экономической зоны в Калининградской области [4], П.В. Павлов уделил внимание оценке эффективности функционирования особых экономических зон [5], а М.А. Сорокин рассмотрел таможенное регулирование как институциональный системный фактор государственной поддержки предпринимательской деятельности на территории свободного порта Владивосток [6]. Что касается непосредственно применения таможенной процедуры свободной таможенной зоны в разных правовых режимах, то следует отметить работу А.К. Тугушева в аспекте ЕАЭС [7], 3.С. Рудневой касательно территорий опережающего социально-экономического развития [8].

Определенный научный интерес представляет работа К.Н. Нилова и А.А. Серебряковой, посвященная проблемам правового регулирования таможенной процедуры свободной таможенной зоны на территории Калининградской области [9]. Они исследовали судебную практику применения законодательства в указанной сфере и пришли к выводам, которые можно применять и к свободному порту Владивосток с учетом особенностей нормативного регулирования. Так, резиденты $0 Э 3$ Калининградской области часто привлекаются к административной ответственности по ст. 16.19 КоАП РФ (Несоблюдение таможенной процедуры) [9, с. 64]. Кроме того, в судебной практике встречаются споры и по конкретной дате начала применения новых положений таможенного законодательства, и споры относительно вопросов достаточной переработки товаров [9, с. 66].

В качестве мер по совершенствованию механизма таможенной процедуры СТЗ, применяемой в Калининградской области, К.Н. Нилов и А.А. Серебрякова предлагают: 1) создание информационного банка данных, обеспечивающего оперативное изменение и корректировку таможенно-тарифной политики ОЭЗ в Калининградской области, то есть гибкое таможенно-тарифное регулирование; 2) включение в законодательство об ОЭЗ в Калининградской области перечня товаров, в отношении которых применяются специальные меры таможенного регулирования; 3) оптимизацию структуры таможенного тарифа, позволяющую расширить внутреннее производство за счет импортных компонентов и при этом предлагать продукцию на внешнем и внутреннем рынках по более конкурентным ценам. Авторы в качестве целей введения подобных мер указывают ограждение местных производителей от недобросовестной конкуренции импортной продукции и превращение СТЗ в эффективный и действенный инструмент поддержки областной промышленности [9, с. 67].

Ф3-212 действует больше года, резиденты СПВ еще не приступили к работе, поэтому сложно на данный момент говорить о конкретных недостатках законодательства, регулирующее применение таможенной процедуры СТЗ в Приморском крае. Однако исследования, проводимые среди зарубежных инвесторов в РФ, позволяют отметить главный недостаток российского рынка - непрозрачность таможенных процедур [10;11]. Отечественные предприниматели высказывают претензии по поводу излишнего регулировании деятельности резидентов СПВ. В каче- 
стве одного из примеров следует привести приказ Министерства финансов Российской Федерации от 22.04.2016 №53н «Об утверждении требований к обустройству и оборудованию территории свободного порта Владивосток, на которой применяется таможенная процедура свободной таможенной зоны» [12] (далее - приказ №53н). Общественный экспертный совет по экономической политике Приморского края подверг резкой критике положения указанного приказа [13].

Приказ №53н определяет требования к обустройству и оборудованию территории СПВ, на которой применяется таможенная процедура СТЗ, в том числе к участкам СПВ, на которых может применяться таможенная процедура СТЗ, предусмотренная для портовой или логистической особой экономической зоны, а также к участку территории СПВ, который находится во владении, в том числе в аренде, у резидента СПВ и на котором может применяться таможенная процедура СТЗ. В документе установлены цели обеспечения эффективности таможенного контроля (п. 1), в части: а) обозначения границы портового и логистического участков СПВ, а также участка резидента СПВ; б) состава зданий, помещений, сооружений, включая ограждение территории портовых и логистических участков СПВ и участка резидента СПВ, необходимых для совершения таможенных операций и проведения таможенного контроля на территории портовых и логистических участков СПВ, а также участка резидента СПВ; в) оснащения и оборудования объектов таможенной инфраструктуры материально-техническими средствами, включая комплекс информационно-технических средств (далее - КИТС); г) обустройства и оборудования территории портовых и логистических участков СПВ, а также участка резидента СПВ.

Этапы и сроки создания таможенной инфраструктуры на портовых и логистических участках СПВ устанавливаются решением наблюдательного совета СПВ. Состав объектов таможенной инфраструктуры на территориях портовых и логистических участков СПВ (участка резидента СПВ) и места их расположения на территории таких участков определяются ФТС России (таможенным органом, в регионе деятельности которого расположен участок резидента СПВ) с учетом: 1) наличия системы учета товаров, помещенных под таможенную процедуру СТЗ, и товаров, изготовленных (полученных) с использованием товаров, помещенных под таможенную процедуру СТ3; 2) физико-географических условий местности; 3) наличия транспортных магистралей (подъездных путей); 4) количества резидентов СПВ; 5) предполагаемого товаропотока и возможного его увеличения на перспективу; 6) поэтапности обустройства и ма- териально-технического оснащения территории СПВ; 7) других факторов, которые могут непосредственно влиять на организацию проведения таможенного контроля.

Для организации таможенного контроля каждый объект таможенной инфраструктуры СПВ должен быть оборудован КИТС, что отражается в решениях наблюдательного совета СПВ. Объекты таможенной инфраструктуры могут создаваться на территории СПВ для организации проведения таможенного контроля как на постоянной основе, так и временно, например, в целях обеспечения проведения строительных и иных работ и ввоза (вывоза) строительных материалов, техники, негабаритных грузов на (c) территорию(ии) СПВ (п. 5 приказа №53н).

Территория портовых и логистических участков СПВ должна иметь ограждение, позволяющее визуально определить ее границы, которое должно быть непрерывным по всему периметру, за исключением мест для входа (выхода) физических лиц, для ввоза (вывоза) товаров и транспортных средств на (c) территорию(ии) СПВ и мест, граничащих с участком(ами) акватории морского (речного) порта. Кроме того, ограждение должно исключать возможность перемещения товаров и транспортных средств на (c) территорию(ии) портовых и логистических участков СПВ вне мест, установленных для ввоза (вывоза) товаров и транспортных средств на (c) территорию(ии) портовых и логистических участков СПВ.

Территория портовых и логистических участков СПВ в пределах ее границ должна быть обустроена и оборудована объектами таможенной инфраструктуры с учетом следующих требований (п.9 приказа №53н). Во-первых, во всех местах въезда (выезда) и (или) входа (выхода) на (c) территорию(ии) портовых и логистических участков СПВ должны располагаться контрольно-пропускные пункты (далее - КПП), оборудованные и технически оснащенные для проведения таможенного контроля товаров и транспортных средств, въезжающих (выезжающих) на (c) территорию(ии) портовых и логистических участков СПВ, товаров, вносимых (выносимых) на (с) территорию(ии) портовых и логистических участков СПВ.

Во-вторых, на территории портовых и логистических участков СПВ должны быть выделены помещения (площадки), освещенные в темное время суток и предназначенные для: хранения задержанных таможенным органом товаров; стоянки транспортных средств, находящихся под таможенным контролем; стоянки транспортных средств, у которых при проведении радиационного контроля выявлен повышенный радиационный фон. 
B-третьих, на территории портовых и логистических участков СПВ должны быть обустроенные здания или офисные помещения, предназначенные для размещения подразделений таможенного органа с учетом его численности, с оборудованными рабочими местами должностных лиц таможенных органов, оснащенные средствами телекоммуникаций. Контрольно-пропускные пункты, здания, площадки и иные сооружения, на территории которых будут производиться операции, связанные с разгрузкой, погрузкой или временным хранением товаров, должны быть оборудованы системой видеонаблюдения с выводом изображений от подключаемых камер на автоматизированное рабочее место должностного лица таможенного поста.

На территории портовых и логистических участков СПВ должны быть помещения и сооружения (площадки), предназначенные для проведения таможенного контроля в отношении товаров и транспортных средств в форме таможенного осмотра (досмотра), оснащенные техническими средствами таможенного контроля (далее - ТСТК). Площадки при необходимости оборудуются боксами досмотра грузовых автотранспортных средств и средствами малой механизации. И наконец, объекты таможенной инфраструктуры портовых и логистических участков СПВ, могут располагаться на специально выделенном на территории портовых и логистических участков СПВ участке, который должен быть огорожен с учетом требований, и определяется как таможенный терминал СПВ.

В случае ввоза (вывоза) товаров на (c) территорию(ии) портовых и логистических участков СПВ (за исключением участка резидента СПВ) осуществляется различными видами транспорта, то для каждого вида транспорта должно функционировать не менее одного КПП (п.9.1 приказа №53н).

Обустройство и оборудование участка резидента СПВ в целях проведения таможенного контроля осуществляется с учетом того, что территория участка резидента СПВ должна иметь ограждение, позволяющее визуально определить ее границы, которое должно быть непрерывным по всему периметру, за исключением мест для входа (выхода) физических лиц, для ввоза (вывоза) товаров и транспортных средств на (c) территорию(ии) участка резидента СПВ и исключать возможность перемещения товаров и транспортных средств на (c) территорию(ии) резидента СПВ вне мест, установленных для ввоза (вывоза) товаров и транспортных средств на (c) территорию(ии) резидента СПВ, а также иметь высоту не менее 2,5 метра (п. 10 приказа №53н). Территория участка резидента СПВ в пределах его границ должна быть обустроена и оборудована объектами таможенной инфраструктуры.
Как видно из анализа приказа №53н, он содержит положения, сходные с теми, которые устанавливаются для любой территории, на которой применяется таможенная процедура СТЗ или осуществляется таможенный контроль. Так, приказ Федеральной таможенной службы от 20 июня 2012 г. №1222 утверждает требования к обустройству, оборудованию и месту нахождения складов временного хранения и прилегающей к ним территории, расположенных на железнодорожных станциях, приближенных к Государственной границе Российской Федерации и являющихся местом расположения таможенных органов или их структурных подразделений, осуществляющих таможенные операции и таможенный контроль в отношении товаров, перемещаемых через таможенную границу Таможенного союза [14]. Еще один приказ указанной службы от 19.08.2014 №1600 содержит требования к обустройству, оборудованию и месту нахождения складов временного хранения и прилегающей к ним территории, приближенных к государственной границе Российской Федерации и являющихся местом расположения таможенных органов или их структурных подразделений, осуществляющих таможенные операции и таможенный контроль в отношении товаров, перемещаемых через таможенную границу Таможенного союза [15]. Нормы специального характера, применяемые к особым экономическим зонам, содержатся и в приказе ФТС России от 30.04.2015 №817 [16].

Для подтверждения тезиса о достаточности правового регулирования применения таможенной процедуры СТЗ в части оборудования соответствующих территорий обратимся к опыту зарубежных стран. Мы неоднократно указывали на относительное совершенство правового регулирования особых экономических зон в США (т.наз. внешнеторговых зон, далее - ВТ3) [17;18], поэтому в качестве предмета исследования возьмем законодательство этого государства.

Правовую основу функционирования ВТЗ составляют Федеральный акт о ВТЗ 1934 г. и два регламента - Регламент Совета по ВТЗ и Регламент Таможенно-пограничной службы США. Отдельные положения закреплены также в других законах и регламентах. Федеральный закон о ВТЗ 1932 г., Гармонизированный тариф США, кодифицированный в титуле 19 Кодекса США, положения §541-552 титула 18 Кодекса США, отображающие положения Федерального закона о тарифах 1930 г., составляют большую часть таможенно-пограничного законодательства. Особое место занимает Регламент Таможенно-пограничной службы США о внешнеторговых зонах, включенный в свод федеральных нормативных актов США [19]. Таможенно-пограничная служба США (U.S. Customs and Border 


\section{Административное и муниципальное право 8 (104) • 2016}

Protection, далее - ТПС) выполняет большинство функций и обязанностей Министра торговли в соответствии с Федеральным актом о ВТЗ. Они включают в себя подготовку и имплементацию правил и регламентов, утверждаемых Секретарем Казначейства согласно Федеральному акту о ВТЗ (19 U.S.C. §81c, §81e, §81o(b)), а также назначение персонала ТПС, необходимого для выполнения функций, предусмотренных 19 U.S.C. §81d. Однако ТПС не представляет Секретаря Казначейства в вопросах ВТ3, которые касаются (1) определения стратегии развития или (2) исполнения полномочий других агентств Министерства финансов, не делегированных Таможенно-пограничной службе США (например, Бюро по налогообложению и торговле табаком и алкоголем (Alcohol \& Tobacco Tax and Trade Bureau (TTB)) или Налоговой службы США (Internal Revenue Service (IRS)).

Основная задача ТПС - контроль над движением грузов в зону и из нее, защита доходов государства и обеспечение соответствия деятельности в зонах законодательству о ВТЗ. Политика нейтралитета ТПС основывается на ее особом статусе это правоприменительный орган власти, который не может поощрять или препятствовать созданию или использованию зон. Сотрудники ТПС не уполномочены консультировать по вопросам преимуществ в использовании разных зон или использования зон вместо других административных механизмов на таможенной территории США.

Комиссар Таможенно-пограничной службы США (The Commissioner of CВР) согласно делегированным полномочиям от Министра финансов назначает персонал ТПС для защиты доходов и контроля над ввозом товаров на таможенную территорию США (19 U.S.C. §81d). Расходы по созданию дополнительных постов ТПС возлагаются, согласно Федеральному акту о ВТЗ, на оператора зоны (19 U.S.C. §81n). До недавнего времени ТПC обеспечивала доходы от ВТЗ путем осуществления физического контроля движения товара в зону и из нее, а также операций по переработке на территории зоны. На сегодняшний день ТПС использует метод аудиторской проверки, которая заключается в следующем: 1) определение идентичности и характера товара до или после его хранения в зоне, поэтому ответственность оператора за товар может быть достоверно определена; 2) выдача предварительного разрешения оператору для ввоза, вывоза и любой обработки в зоне; 3) презумпция ответственности оператора за товар в зоне, в том числе физический надзор, безопасность, ведение документации, соблюдение условий хранения и обработки (количество товара определяется совместно оператором и перевозчиком); 4) осуществление ТПС аудита и проверки соответствия для подтверждения выполнения оператором требований законодательства по осуществлению контроля в ВТЗ и ведению учетных записей; 5) адекватное обеспечение оператором возможной неустойки при невыполнении обязательств по осуществлению контроля; 6) полномочия ТПС по приостановлению активного статуса оператора на срок не более 90 дней или аналогичные полномочия Совета по ВТЗ по продлению такового на более длительный срок в случае несоответствия его деятельности законодательству о BT3 (19 CFR 146.82). Директор порта может в любое время рекомендовать Совету по ВТЗ приостановить функционирование ВТЗ по причине умышленных и регулярных нарушений Федерального акта о BT3 (19 CFR 146.83).

Пределы и природа контроля ТПС в ВТЗ предусмотрены в 19 U.S.C. §81a-u, 19 CFR 1646a, 19 CFR 161.2, 19 CFR 146. Директор порта может уточнить, назначить или запросить у ТПС проведение проверки любой операции или процедуры в ВТЗ. ТПС осуществляет контроль путем проверки документации, инвентаризации товара, проверки на соответствие определенных операций или процедур, аудита бухгалтерской документации, проверки условий хранения и безопасности (19 CFR 146.3).

Представляет научный и практический интерес такой институт как подзона ВТЗ. Она определяется как внешнеторговая зона специального назначения, являющаяся частью конкретной существующей ВТЗ, используемая для осуществления определенной деятельности, которая не может осуществляться в конкретной существующей ВТ3 из-за ее месторасположения (19 CFR 146.1(b) (17); 15 CFR 400.2(n)). Подзона может быть создана, если Совет по ВТЗ посчитает, что определенный вид деятельности не может осуществляться на территории существующей ВТЗ и требует другого местоположения, и предполагает проведение проверки на соответствие общественному интересу 15 CFR 400.23(b). По общему правилу, ВТ3 должна быть расположена на расстоянии максимум 60 миль или 90 минут езды от пункта Таможенно-пограничной службы США. Для подзоны такого требования не существует, что и оправдывает существование такой разновидности ВТЗ и способствует созданию подзоны, приписанной к конкретной ВТЗ, в местах расположения уже существующих производственных мощностей резидента ВТЗ. Поэтому возможно применение таможенных процедур, в том числе и СТЗ, на отдельно взятом предприятии, имеющем статус подзоны ВТЗ.

Эффективность таможенного контроля достигается путем использования метода «пакетного» ввоза ("bundling" of entries) и служит еще 
одним источником экономии для операторов ВТЗ («пакет» складывается из документов отдельных партий товаров, подлежащих ввозу или вывозу). В дополнение к снижению временных затрат и затрат на бумажное оформление, «пакетный» ввоз позволяет импортеру подать документы за целую неделю сразу и оплатить разовый сбор за оформление товаров (merchandise processing fees (MPFs) - от \$25 до \$485) вместо оформления каждой партии товара отдельно. Таким образом пользователи зон, имеющие значительный оборот товара, экономят до 90\% расходов на таможенное оформление 90\%. Сбор за оформление товаров (merchandise processing fees (MPFs)) составляет $0.3464 \%$ от стоимости товара, но не может превышать \$485. Благодаря этому, разовый недельный сбор уменьшает MPFs для компаний, чей еженедельный импорт превышает \$140,011.55 - максимально облагаемую сумму [20].

Национальная ассоциация ВТ3 (The National Association of Foreign Trade Zones (NAFTZ)) утверждает, что на ВТЗ ежегодно приходится более $10 \%$ импорта США в денежном эквиваленте, но менее $1 \%$ таможенных оформлений ТПС благодаря «пакетному» оформлению импорта. Для крупной компании с 10 хранилищами по всей стране и несколькими сотнями доставок в неделю, «пакетное» оформление позволяет ежегодно экономить от 25 тыс. до 2 млн. долларов [21].

Что касается оборудования территории, на которой осуществляется таможенная процедура СТЗ и таможенный контроль, то в январе 2016 года было утверждено новое Руководство по физической безопасности для оборудования помещений, используемых в ВТЗ [22].

В соответствии с положениями указанного документа, собственники, осуществляющие деятельность в ВТЗ, обязаны разработать специальный план физической безопасности в соответствии с требования ТПС США, который должен пересматриваться каждый год с целью обеспечения эффективности всех указанных мер. Данный план должен отражать несколько аспектов безопасности. Первый касается необходимости определения физических границ (т.е. ограждение) и охраны. Отдельно должны быть определены системы сигнализации и видеонаблюдения (обязательна архивация видеоданных). Предъявляются требования к материалам, используемым для ограждения и постройки помещений (обязательны регулярные проверка состояния материалов и ремонт). Системы безопасности (противопожарная система, система радиационного контроля, система обнаружения опасных газов, воздухо- и газоочистители) должны проверяться на регулярной основе на предмет неавторизованного вмешательства или выключения. Безопасность ограждений (по периметру) должна регулярно проверяться, должны быть разработаны инструкции к действию в случае неавторизованных проникновений. Въездные (выездные) ворота должны физически охраняться и контролироваться через систему видеонаблюдения. Необходимо поддерживать достаточный уровень освещения как внутри, так и снаружи помещений, включая ворота, места расположения грузов, ограждения и места для паркования.

Что качается запирающих устройств и элементов управления, то они должны контролироваться персоналом охраны или руководством, охватывая внешние и внутренние окна, ворота, и ограждения.

Парковочные места должны использоваться в целях осуществления деятельности ВТЗ, поэтому должны быть обеспечены отдельные парковочные места для личного и служебного транспорта.

Особое внимание уделяется системе контроля физического доступа: она должна предусматривать идентификацию всех сотрудников, посетителей и поставщиков подтверждением (т. наз. позитивная идентификация) на всех участках доступа.

Безопасность перемещения грузов обеспечивается путем разработки процедур инспектирования средств перевозки (прицепов и контейнеров) до погрузки с целью недопущения неучтенных товаров и грузов. Такое инспектирование предусматривает как проверку средств перевозки, упаковочных материалов, так и лиц, осуществляющих погрузку (разгрузку), а также находящихся в такие моменты в непосредственной близости. Кроме того, к перевозке должны быть допущены сертифицированные перевозчики.

Особое внимание уделяется персоналу, допускаемому на территорию с особым режимом. В плане должны быть предусмотрены и регулярно осуществляться программы как обычной (физической), так и антитеррористической безопасности. Для персонала, занятого на погрузке (разгрузке) товара, а также почтовой корреспонденции, должны быть разработаны специальные программы безопасности. Кроме того, необходима специальная подготовка по обеспечению целостности груза, распознаванию преступных сговоров и защите систем контроля доступа. Устанавливаются также требования к информационной безопасности с обязательной подготовкой персонала в этой сфере.

Как видно из анализируемого нормативного акта, законодатель США достаточно подробно регулирует порядок оборудования территорий ВТЗ, на которых используется таможенная процедура СТЗ и осуществляется таможенный контроль. Следовательно, ужесточение требований к подобным территориям является обоснованной и необходимой мерой, применяемой в тех государствах, 


\section{Административное и муниципальное право 8 (104) • 2016}

которые осознанно подходят к применению мер государственной поддержки в особых экономических зонах, привлекая инвесторов и в то же время осуществляя контроль, необходимый для выполнения фискальных функций. Именно отсутствие действенного государственного контроля в XIX-XX вв. стало одной из причин неудовлетворительного экономического эффекта от режима порто-франко на Дальнем Востоке. По нашему мнению, в настоящей ситуации ученым и практикам необходимо приложить усилия в отношении обеспечения прозрачности таможенных процедур. Совершенствование применения таможенной процедуры СТЗ на территории свободного порта Владивосток должно осуществляться с учетом опыта уже давно функционирующих особых экономических зон.

\section{Библиография:}

1. Грец М.Г. Таможенный режим на особых территориях государств - членов Таможенного союза ЕврАзЭС / М.Г. Грец // Журнал правовых и экономических исследований. 2011. № 3. С. 33-35.

2. Сысоев А.П. Общие вопросы формирования и функционирования особых экономических зон в Российской Федерации / А.П. Сысоев // Особые экономические зоны Российской Федерации: проблемы становления, регулирования и развития. М.: Изд-во Моск. госуд. ун-та им. М.В. Ломоносова, 2012. С. 11-43.

3. Ларионов С.А. Таможенная процедура свободной таможенной зоны: от Таможенного союза к Всемирной торговой организации / С.А. Ларионов // Научные труды SWorld. 2012. T. 18. № 1. С. 62-64.

4. Нилов К.Н. Правовой режим особой экономической зоны в Калининградской области: проблемы совершенствования / К.Н. Нилов // Вестник Балтийского федерального университета им. И. Канта. Серия: Гуманитарные и общественные науки. 2011. № 9. С. 65-72

5. Павлов П.В. Оценка эффективности функционирования особых экономических зон: правовое регулирование и экономическое содержание / П.В. Павлов // Административное и муниципальное право. 2014. № 6. С. $520-532$

6. Сорокин М.А. Таможенное регулирование в системе институциональных факторов государственной поддержки предпринимательской деятельности на территории свободного порта Владивосток / М.А. Сорокин // Экономика и менеджмент систем управления. 2015. Т. 16. № 2. С. 81-87.

7. Тугушев А.К. Особенности правового регулирования таможенной процедуры свободной таможенной зоны в ЕАЭС / А.К. Тугушев // Актуальные проблемы таможенного дела и евразийской интеграции. 2016. С. 181-188.

8. Руднева 3.С. Проблемы применения таможенной процедуры свободной таможенной зоны на площадках территорий опережающего социально-экономического развития / 3.С. Руднева // Известия Тульского государственного университета. Экономические и юридические науки. 2016. № 2-1. С. 153-159.

9. Нилов К.Н., Серебрякова А.А. Проблемы правового регулирования таможенной процедуры свободной таможенной зоны на территории Калининградской области / К.Н. Нилов, А.А. Серебрякова // Вестник Балтийского федерального университета им. И. Канта. Серия: Гуманитарные и общественные науки. 2013. № 9. С. 61-69.

10. Грачева М.В. Развитие германского бизнеса в России в 2014-2015 гг:: мнение руководителей / М.В. Грачева / Российский экономический барометр. 2014. № 4(56). С. 10-16, с. 16.

11. Грачева М.В. Мнение германских предпринимателей о развитии бизнеса в России в 2012 - 2013 годах / М.В. Грачева // Российский экономический барометр. 2013. № 3(51). С. 12-18.

12. Об утверждении требований к обустройству и оборудованию территории свободного порта Владивосток, на которой применяется таможенная процедура свободной таможенной зоны: приказ Минфина России от 22.04.2016 №53н [Электронный ресурс] // СПС «КонсультантПлюс». - Режим доступа: http://base.consultant.ru/cons/cgi/ online.cgi?req=doc;base=LAW;n=198569 (дата обращения: 18.07.2016)

13. Таможня делает Свободный порт Владивосток несвободным - экспертный совет [Электронный ресурс] // TKS. $\mathrm{RU}$ - все о таможне. Таможня для всех - российский таможенный портал. - Режим доступа: http://www.tks.ru/ logistics/2016/05/05/0005 (дата обращения - 18.07.2016)

14. Об утверждении требований к обустройству, оборудованию и месту нахождения складов временного хранения и прилегающей к ним территории, расположенных на железнодорожных станциях, приближенных к Государственной границе Российской Федерации и являющихся местом расположения таможенных органов или их структурных подразделений, осуществляющх таможенные операции и таможенный контроль в отношении товаров, перемещаемых через таможенную границу Таможенного союза: приказ Федеральной таможенной службы от 20 июня 2012 г. № 1222 [Электронный ресурс] // СПС «КонсультантПлюс». - Режим доступа: http://base. consultant.ru/cons/cgi/online.cgi?req=doc;base=LAW;n=134534 (дата обращения - 18.07.2016)

15. Об утверждении требований к обустройству, оборудованию и месту нахождения складов временного хранения и прилегающей к ним территории, приближенных к государственной границе Российской Федерации и являющихся местом расположения таможенных органов или их структурных подразделений, осуществляющих таможенные операции и таможенный контроль в отношении товаров, перемещаемых через таможенную границу Таможенного союза: приказ ФТС России от 19.08.2014 № 1600 [Электронный ресурс] // СПС «КонсультантПлюс». - Режим доступа: http://base.consultant.ru/cons/cgi/online.cgi?req=doc;base=LAW;n=169941 (дата обращения - 18.07.2016)

16. Об утверждении требований к обустройству и оборудованию территории особой экономической зоны и требований к обустройству и оборудованию земельных участков, предоставленных резидентам особой экономической зоны, в случаях, предусмотренных частью 4 статьи 37.2 Федерального закона от 22 июля 2005 г. № 116 -Ф3 «Об особых экономических зонах в Российской Федерации», а также порядка обеспечения контрольно-пропускного режима на территории особой экономической зоны, включая порядок доступа лиц на такую территорию: 
приказ ФТС России от 30.04.2015 №817 [Электронный ресурс] // СПС «КонсультантПлюс». - Режим доступа: http://base.consultant.ru/cons/cgi/online.cgi?req=doc;base=LAW;n=180487 (дата обращения - 18.07.2016)

17. Горян Э.В. Программа внешнеторговых зон США: национальная концепция института особой экономической зоны / Э.В. Горян // Административное и муниципальное право. 2015. № 11. C. 1112-1120. DOI: 10.7256/19992807.2015.11.16753

18. Горян Э.В. Становление института подзоны особой экономической зоны в США / Э.В. Горян // Административное и муниципальное право. 2015. № 10. C. 1029-1038. DOI: 10.7256/1999-2807.2015.10.16480

19. Code of Federal Regulations, 19 CFR 146 - FTZ Regulations [Электронный ресурс]. - Режим доступа: http://www.gpo. gov/fdsys/granule/CFR-2012-title19-vol2/CFR-2012-title19-vol2-part146 (дата обращения - 18.07.2016)

20. User fee - Merchandise Processing Fees // U.S. Customs and Border Protection [Электронный ресурс]. - Режим доступа: https://help.cbp.gov/app/answers/detail/a_id/334/ /user-fee---merchandise-processingfees (дата обращения 18.07.2016)

21. Annual Report of the Foreign-Trade Zones Board to the Congress of the United States. 2014 [Электронный ресурс]. Режим доступа: http://enforcement.trade.gov/ftzpage/annualreport/ar-2014.pdf (дата обращения - 18.07.2016)

22. Physical Security Guidelines for CBP Bonded Facilities [Электронный peсурс]. - Режим доступа: http://www.naftz.org/ wp-content/uploads/2016/05/FTZ-Security-Guidelines-Appendix-B.pdf (дата обращения - 18.07.2016)

23. Горян Э.В. Перспективы создания особой экономической зоны «свободный порт Владивостока»: сравнительноправовой анализ // Право и политика. 2015. № 4. C. 467 - 475. DOI: 10.7256/1811-9018.2015.4.14786.

\section{References (transliterated):}

1. Grets M.G. Tamozhennyi rezhim na osobykh territoriyakh gosudarstv - chlenov Tamozhennogo soyuza EvrAzES / M.G. Grets // Zhurnal pravovykh i ekonomicheskikh issledovanii. 2011. № 3. S. 33-35.

2. Sysoev A.P. Obshchie voprosy formirovaniya i funktsionirovaniya osobykh ekonomicheskikh zon v Rossiiskoi Federatsii / A.P. Sysoev // Osobye ekonomicheskie zony Rossiiskoi Federatsii: problemy stanovleniya, regulirovaniya i razvitiya. M.: Izd-vo Mosk. gosud. un-ta im. M.V. Lomonosova, 2012. S. 11-43.

3. Larionov S.A. Tamozhennaya protsedura svobodnoi tamozhennoi zony: ot Tamozhennogo soyuza k Vsemirnoi torgovoi organizatsii / S.A. Larionov // Nauchnye trudy SWorld. 2012. T. 18. № 1. S. 62-64.

4. Nilov K.N. Pravovoi rezhim osoboi ekonomicheskoi zony v Kaliningradskoi oblasti: problemy sovershenstvovaniya / K.N. Nilov // Vestnik Baltiiskogo federal'nogo universiteta im. I. Kanta. Seriya: Gumanitarnye i obshchestvennye nauki. 2011. № 9. S. 65-72

5. Pavlov P.V. Otsenka effektivnosti funktsionirovaniya osobykh ekonomicheskikh zon: pravovoe regulirovanie i ekonomicheskoe soderzhanie / P.V. Pavlov // Administrativnoe i munitsipal'noe pravo. 2014. № 6. S. 520-532

6. Sorokin M.A. Tamozhennoe regulirovanie $\mathrm{v}$ sisteme institutsional'nykh faktorov gosudarstvennoi podderzhki predprinimatel'skoi deyatel'nosti na territorii svobodnogo porta Vladivostok / M.A. Sorokin // Ekonomika i menedzhment sistem upravleniya. 2015. T. 16. № 2. S. 81-87.

7. Tugushev A.K. Osobennosti pravovogo regulirovaniya tamozhennoi protsedury svobodnoi tamozhennoi zony v EAES / A.K. Tugushev // Aktual'nye problemy tamozhennogo dela i evraziiskoi integratsii. 2016. S. 181-188.

8. Rudneva Z.S. Problemy primeneniya tamozhennoi protsedury svobodnoi tamozhennoi zony na ploshchadkakh territorii operezhayushchego sotsial'no-ekonomicheskogo razvitiya / Z.S. Rudneva // Izvestiya Tul'skogo gosudarstvennogo universiteta. Ekonomicheskie i yuridicheskie nauki. 2016. № 2-1. S. 153-159.

9. Nilov K.N., Serebryakova A.A. Problemy pravovogo regulirovaniya tamozhennoi protsedury svobodnoi tamozhennoi zony na territorii Kaliningradskoi oblasti / K.N. Nilov, A.A. Serebryakova // Vestnik Baltiiskogo federal'nogo universiteta im. I. Kanta. Seriya: Gumanitarnye i obshchestvennye nauki. 2013. № 9. S. 61-69.

10. Gracheva M.V. Razvitie germanskogo biznesa v Rossii v 2014-2015 gg.: mnenie rukovoditelei / M.V. Gracheva / Rossiiskii ekonomicheskii barometr. 2014. № 4(56). S. 10-16, s. 16.

11. Gracheva M.V. Mnenie germanskikh predprinimatelei o razvitii biznesa v Rossii v 2012 - 2013 godakh / M.V. Gracheva // Rossiiskii ekonomicheskii barometr. 2013. № 3(51). S. 12-18.

12. Ob utverzhdenii trebovanii $\mathrm{k}$ obustroistvu i oborudovaniyu territorii svobodnogo porta Vladivostok, na kotoroi primenyaetsya tamozhennaya protsedura svobodnoi tamozhennoi zony: prikaz Minfina Rossii ot 22.04.2016 №53n [Elektronnyi resurs] // SPS «Konsul'tantPlyus». - Rezhim dostupa: http://base.consultant.ru/cons/cgi/online. cgi?req=doc;base=LAW;n=198569 (data obrashcheniya: 18.07.2016)

13. Tamozhnya delaet Svobodnyi port Vladivostok nesvobodnym - ekspertnyi sovet [Elektronnyi resurs] // TKS.RU vse o tamozhne. Tamozhnya dlya vsekh - rossiiskii tamozhennyi portal. - Rezhim dostupa: http://www.tks.ru/ logistics/2016/05/05/0005 (data obrashcheniya - 18.07.2016)

14. Ob utverzhdenii trebovanii k obustroistvu, oborudovaniyu i mestu nakhozhdeniya skladov vremennogo khraneniya i prilegayushchei knim territorii, raspolozhennykh na zheleznodorozhnykh stantsiyakh, priblizhennykh k Gosudarstvennoi granitse Rossiiskoi Federatsii i yavlyayushchikhsya mestom raspolozheniya tamozhennykh organov ili ikh strukturnykh podrazdelenii, osushchestvlyayushchikh tamozhennye operatsii i tamozhennyi kontrol' $\mathrm{v}$ otnoshenii tovarov, peremeshchaemykh cherez tamozhennuyu granitsu Tamozhennogo soyuza: prikaz Federal'noi tamozhennoi sluzhby ot 20 iyunya 2012 g. № 1222 [Elektronnyi resurs] // SPS «Konsul'tantPlyus». - Rezhim dostupa: http://base.consultant.ru/ cons/cgi/online.cgi?req=doc;base=LAW;n=134534 (data obrashcheniya -18.07 .2016 )

15. Ob utverzhdenii trebovanii k obustroistvu, oborudovaniyu i mestu nakhozhdeniya skladov vremennogo khraneniya i prilegayushchei k nim territorii, priblizhennykh k gosudarstvennoi granitse Rossiiskoi Federatsii i yavlyayushchikhsya 
mestom raspolozheniya tamozhennykh organov ili ikh strukturnykh podrazdelenii, osushchestvlyayushchikh tamozhennye operatsii i tamozhennyi kontrol' v otnoshenii tovarov, peremeshchaemykh cherez tamozhennuyu granitsu Tamozhennogo soyuza: prikaz FTS Rossii ot 19.08.2014 № 1600 [Elektronnyi resurs] // SPS «Konsul'tantPlyus». Rezhim dostupa: http://base.consultant.ru/cons/cgi/online.cgi?req=doc;base=LAW;n=169941 (data obrashcheniya 18.07.2016)

16. Ob utverzhdenii trebovanii $\mathrm{k}$ obustroistvu i oborudovaniyu territorii osoboi ekonomicheskoi zony i trebovanii $\mathrm{k}$ obustroistvu i oborudovaniyu zemel'nykh uchastkov, predostavlennykh rezidentam osoboi ekonomicheskoi zony, $\mathrm{v}$ sluchayakh, predusmotrennykh chast'yu 4 stat'i 37.2 Federal'nogo zakona ot 22 iyulya 2005 g. № 116 -FZ «Ob osobykh ekonomicheskikh zonakh v Rossiiskoi Federatsii», a takzhe poryadka obespecheniya kontrol'no-propusknogo rezhima na territorii osoboi ekonomicheskoi zony, vklyuchaya poryadok dostupa lits na takuyu territoriyu: prikaz FTS Rossii ot 30.04.2015 №817 [Elektronnyi resurs] // SPS «Konsul'tantPlyus». - Rezhim dostupa: http://base.consultant.ru/cons/ cgi/online.cgi?req=doc; base=LAW;n=180487 (data obrashcheniya -18.07 .2016 )

17. Goryan E.V. Programma vneshnetorgovykh zon SShA: natsional'naya kontseptsiya instituta osoboi ekonomicheskoi zony / E.V. Goryan // Administrativnoe i munitsipal'noe pravo. 2015. № 11. S. 1112-1120. D0I: 10.7256/19992807.2015.11.16753

18. Goryan E.V. Stanovlenie instituta podzony osoboi ekonomicheskoi zony v SShA / E.V. Goryan // Administrativnoe i munitsipal'noe pravo. 2015. № 10. S. 1029-1038. DOI: 10.7256/1999-2807.2015.10.16480

19. Code of Federal Regulations, 19 CFR 146 - FTZ Regulations [Elektronnyi resurs]. - Rezhim dostupa: http://www.gpo. gov/fdsys/granule/CFR-2012-title19-vol2/CFR-2012-title19-vol2-part146 (data obrashcheniya - 18.07.2016)

20. User fee - Merchandise Processing Fees // U.S. Customs and Border Protection [Elektronnyi resurs]. - Rezhim dostupa: https://help.cbp.gov/app/answers/detail/a_id/334/ /user-fee---merchandise-processingfees (data obrashcheniya 18.07.2016)

21. Annual Report of the Foreign-Trade Zones Board to the Congress of the United States. 2014 [Elektronnyi resurs]. - Rezhim dostupa: http://enforcement.trade.gov/ftzpage/annualreport/ar-2014.pdf (data obrashcheniya - 18.07.2016)

22. Physical Security Guidelines for CBP Bonded Facilities [Elektronnyi resurs]. - Rezhim dostupa: http://www.naftz.org/ wp-content/uploads/2016/05/FTZ-Security-Guidelines-Appendix-B.pdf (data obrashcheniya - 18.07.2016)

23. Goryan E.V. Perspektivy sozdaniya osoboi ekonomicheskoi zony «svobodnyi port Vladivostoka»: sravnitel'no-pravovoi analiz // Pravo i politika. 2015. № 4. C. 467 - 475. DOI: 10.7256/1811-9018.2015.4.14786. 